\title{
The 'Great Diversification Game': Russia's Vision of the European Union's Energy Projects in the Shared Neighbourhood
}

\section{Valentina Feklyunina}

\begin{abstract}
This article examines Russia's vision of the European Union's energy diversification projects that focus on their 'shared neighbourhood'. It argues that although the European Union (EU), unlike the USA, is not yet seen as a serious threat to Russian interests in the area, this situation is rapidly changing, with the Kremlin becoming increasingly sensitive about the EU's plans to diversify energy supply sources and transportation routes by increasing cooperation with other former Soviet Republics within the Commonwealth of Independent States (CIS). The article highlights how the EU's energy diversification projects are viewed by Moscow as anti-Russian and details the way in which Russia is responding to this perceived threat, including plans to diversify its own energy exports.
\end{abstract}

ENERGY SUPPLY SECURITY HAS BECOME ONE OF THE TOP ISSUES ON THE EU'S POLITICAL agenda. The EU's dependence on Russian energy supplies has grown dramatically in recent years, in part due to the expansion of the EU following its most recent round of enlargement towards Central and Eastern Europe in 2004 and 2007. Recognition of this fact has informed the recent debate on energy supply for Europe. The Russian dispute with Ukraine over gas prices and overdue payments in the winter of 2005-2006 resulted in a drop in the level of supply to some EU member states. This, coupled with a growing acceptance among European states of increased assertiveness of Russian foreign policy under Putin, raised European fears that Russia was prepared to engage in 'pipeline diplomacy' and 'energy blackmailing'. It is feared that this could have detrimental effects on the security of supply of natural gas and crude oil to the EU.

In this context, diversification of energy supply sources and transportation routes is often suggested as a possible way to minimise the risks for the EU of single source dependency. The European Neighbourhood Policy (ENP) is seen as one of the key instruments in achieving this goal, as it aims (inter alia) to strengthen the EU's cooperation with neighbouring countries in the energy sphere. According to the ENP Strategy (2004) "enhancing [...] strategic energy partnership with neighbouring countries is a major element of the European Neighbourhood Policy" (European Commission 2004: 17). Some of the EU's neighbours, such

I would like to thank three anonymous reviewers for their comments and suggestions. Furthermore, I would like to thank Anke Schmidt-Felzmann and Eamonn Butler for their assistance and constructive advice.

ISSN 1815-347X online - Feklyunina, V. (2008). 'The "Great Diversification Game": Russia's Vision of the European Union's Energy Projects in the Shared Neighbourhood', Journal of Contemporary European Research, Vol. 4, No. 2, pp. 130-148. 
as Ukraine, can offer alternative transit routes, including projects such as the existing OdessaBrody-Poland oil pipeline and the proposed White Stream project which would bring natural gas from Central Asia to Europe via Ukraine. Others, such as Azerbaijan, are important for the $\mathrm{EU}$ in terms of both the production and the transit of energy from Central Asia and the Caspian Basin (European Commission 2006d). Moreover, there is a growing interest from the EU in developing cooperation with the energy-rich Central Asian countries - Kazakhstan, Turkmenistan and Uzbekistan - which are not formally part of the ENP, but which, nonetheless, are seen as "neighbours of our neighbours" (European Commission 2006c: 11). The basis of cooperation with these countries is the EU's 'Central Asia Strategy' which was developed and adopted in 2007 during the German EU Presidency (Council of the European Union 2007).

As this article will show however, Russia's policies towards these countries could pose a serious challenge to the ENP's success in the East and to the implementation of the EU's strategy for Central Asia. This is due to the fact that Russia has become increasingly sensitive about the EU's actions on the territory of the former Soviet Union, specifically because it views this region as being within its own sphere of 'legitimate interest'. Effectively, the region can be viewed as a 'shared neighbourhood', ' however, the divergence between the respective EU and Russian interests in the region, both perceived and objective, is especially wide, particularly with regard to energy cooperation and the problem of energy security. Understanding this divergence in interests, from the perspective of both parties, should be paramount; unfortunately, most of the current literature written by western-based scholars has focused predominately on the EU's perceptions of the situation and there has been little attention given to understanding Russian perceptions of the EU's energy cooperation with the CIS countries. There is an obvious lacuna within the literature that needs to be addressed and this article aims to contribute to filling the gap. It will do this by examining how the recent developments in EU policy towards the 'shared neighbourhood' are viewed by Moscow. Specifically, it addresses the question of how Russian perceptions of the EU's energy projects in the post-Soviet area shape visions of Russia's national interest, and consequently shape the Kremlin's policy towards the region, vis-à-vis the EU. To this end a range of documents are analysed which reflect the prevalent discourse in the Russian mass media $^{2}$ and the dominant discourse among Russian political elites concerning the country's energy policy. These include official documents ${ }^{3}$ and statements by high-ranking decisionmakers. ${ }^{4}$

The article is organised into four parts. It starts with a brief overview of the reasons behind the different energy diversification projects of the EU and Russia. The second section looks at Russia's views on EU policy towards the 'shared neighbourhood' and shows how these changed following the 2004 Orange Revolution in Ukraine. It also examines how the EU's interpretations of energy security are portrayed in Russia's dominant discourse, and analyses the factors that contribute to Moscow's perceptions of the EU's diversification intentions as a threat. In the third section, the article discusses the advantages Russia perceives itself to have over the EU, and the West in general, in terms of the competition for Central Asian energy resources. The article concludes with a discussion about the implications all of this has for EU-Russian relations, and ultimately for the success of the EU's energy policy in the 'shared neighbourhood'. It argues that although the EU, unlike the USA, is not (yet) considered as a serious threat to Russian interests in the region, this situation is rapidly changing due to the fact that the Kremlin is becoming increasingly sensitive about the EU's intention to diversify its energy supplies by intensifying cooperation with the CIS countries. As will be shown, the

\footnotetext{
${ }^{1}$ It should be noted that in the Russian dominant discourse the former Soviet Union republics are viewed as the 'near abroad' while the rest of the world is the 'far abroad'.

2 This includes print media and the state controlled radio station 'Voice of Russia', and television channel "Channel One". These outlets were chosen because their state ownership and editorial status means that they are more likely to reproduce the dominant political discourse.

${ }^{3}$ These are the Russian Federation's 'Foreign Policy Concept' and its 'Energy Strategy for the Period until 2020 '.

${ }^{4}$ These include former President Vladimir Putin; Minister for Foreign Affairs, Sergey Lavrov, and his deputies; Minister for Industry and Energy, Viktor Khristenko, and his deputies.
} 
divergent visions of energy security held by Russia and the EU create a 'security dilemma' for both.

\section{The ‘EU-Russia-Central Asia’ Triangle: The Pursuit of a ‘Great Diversification Game’?}

Growing EU dependence on energy supplies from the Russian Federation has recently become one of the most important issues on the EU's political agenda. In terms of EU energy consumption, about 24 per cent of natural gas and 27 per cent of oil is supplied by Russia (European Commission 2006b: 5). This dependence is seen by many in Brussels and in the national capitals as posing serious risks to the EU's energy security. The problem has become especially politicised in relation to natural gas supplies, which can largely be explained by the difference in transportation of natural gas and oil. In the trade of crude oil, dependence on a particular supplier (and transit country) is significantly lower, since both suppliers and target countries have more options. Most crude oil is brought to the consumer via a variety of routes, and not limited to the transmission via pipeline. This means that if a producer country decides to cut its oil supply to a consuming country, it is unlikely to have any major effect as the targeted country can make up for the shortfall by buying supplies on the 'spot market' (Goldthau 2008). But it must be noted that for the landlocked countries of Central and Eastern Europe the reliance on oil supply through pipeline transmission remains significant.

Gas supply, on the other hand, is by its nature generally still restricted to transport via pipeline and supply routes are therefore rather inflexible. In order to ensure delivery of gas to a different customer, a producer would have to invest in new pipeline infrastructure, which takes time to construct and requires significant investment upfront; the same logic applies for the consumer. Since the exploration and production of new gas fields and construction of pipelines is extremely expensive and time-consuming, producers and consumers generally negotiate long-term contracts that can run for up to 25 years. For the consumer the certainty of guaranteed supply for several decades also removes any need to build up expensive stocks to buffer supply shocks (Goldthau 2008). The alternative to pipeline transport of gas is Liquefied Natural Gas (LNG)5, however, it is expensive and not a viable alternative in the medium or perhaps even long-term (Goldthau 2008).

Table 1: EU Member States' Gas Imports from Russia (2005)

\begin{tabular}{|l|c|}
\hline Member State & \% of Total Gas Imports from Russia (2005) \\
\hline Austria & 70 \\
\hline Belgium & 8 \\
\hline Bulgaria & 100 \\
\hline Czech Republic & 76 \\
\hline Estonia & 100 \\
\hline Finland & 100 \\
\hline France & 23 \\
\hline Germany & 57 \\
\hline Greece & 84 \\
\hline Hungary & 81 \\
\hline Italy & 36 \\
\hline Latvia & 100 \\
\hline Lithuania & 100 \\
\hline Poland & 68 \\
\hline Romania & 100 \\
\hline Slovakia & 100 \\
\hline Slovenia & 60 \\
\hline Other Member States & 0 \\
\hline EU 27 & $\mathbf{4 2}$ \\
\hline Source:House of Lords & \\
\hline
\end{tabular}

Source: House of Lords (2008: 47).

\footnotetext{
${ }^{5}$ LNG technology allows gas to be shipped in large quantities by tankers, and thus makes it independent from existing pipeline routes.
} 
Table 1 (above) illustrates the share of Russian gas supplies in relation to total gas imports by individual member states and for the EU as a whole. This dependence is likely to increase even further due to the decline of indigenous fossil fuel production in the European Union, as well as the growing share of natural gas in the EU's energy mix. According to International Energy Agency (IEA) estimates, the gap between production and demand in the EU will increase from about 230 billion cubic metres (bcm) in 2002 to $640 \mathrm{bcm}$ in 2030, which means that by 2030 the EU will have to import about $80 \%$ of its gas (IEA 2004).

In this context, diversification of both the sources of supply and the supply routes is seen by the EU as one of the main ways of addressing the problem (European Commission 2006a: 25). In an attempt to reduce its dependence on Russia, Brussels views cooperation with the resource-rich Central Asian countries as key to diversifying the sources of energy. Although the gas reserves of the Central Asian Republics are substantially smaller than those of the Russian Federation, they are still significant (see Table 2 for data on proved reserves, production and consumption of gas in Russia, the EU and three of the Central Asian countries - Kazakhstan, Turkmenistan and Uzbekistan).

Table 2: Natural Gas: Proved Reserves, Production and Consumption (2007).

\begin{tabular}{|l|l|l|l|l|l|l|}
\hline & \multicolumn{2}{|c|}{ Proved reserves } & \multicolumn{2}{c|}{ Production } \\
& $\mathbf{t c m}$ & $\begin{array}{l}\text { Share of } \\
\text { total, \% }\end{array}$ & $\mathbf{b c m}^{\mathbf{7}}$ & $\begin{array}{l}\text { Share of } \\
\text { total, \% }\end{array}$ & bcm & $\begin{array}{l}\text { Share of } \\
\text { total, \% }\end{array}$ \\
\hline $\begin{array}{l}\text { Russian } \\
\text { Federation }\end{array}$ & 44.65 & 25.2 & 607.4 & 20.6 & 438.8 & 15 \\
\hline Kazakhstan & 1.90 & 1.1 & 27.3 & 0.9 & 19.8 & 0.7 \\
\hline Turkmenistan & 2.67 & 1.5 & 67.4 & 2.3 & 21.9 & 0.7 \\
\hline Uzbekistan & 1.74 & 1.0 & 58.5 & 2.0 & 45.6 & 1.6 \\
\hline EU 27 & 2.84 & 1.6 & 191.9 & 6.5 & 481.9 & 16.4 \\
\hline
\end{tabular}

Source: British Petroleum (2008)

According to the EU's 'Central Asia Strategy' (2007), "energy resources in Central Asia and the region's aim to diversify trade partners and supply routes can help meet EU energy security and supply needs" (Council of the European Union 2007: 9). However, the EU's plans to diversify energy imports with the help of Central Asian hydrocarbons (primarily from Kazakhstan and Turkmenistan) need to address some considerable difficulties, such as the geographical location of these countries, before they can be realised. Being landlocked, the Central Asian Republics need to rely on specific transit routes in order to ensure that their gas reaches the European market. To solve this problem, the strategy envisages that the EU will "support the development of additional pipeline routes and energy transportation networks" (Council of the European Union 2007: 19).

The European Commission's Green Paper, 'A European Strategy for Sustainable, Competitive and Secure Energy' (European Commission 2006a), provides an overview of new gas projects that are intended to help the EU diversify energy sources and supply routes. One of these projects is the 'Nabucco Pipeline', which is planned to cross Turkey, Bulgaria, Romania, Hungary and Austria, bringing natural gas from the Caspian region, Iran and the Middle East. Its capacity is supposed to reach $31 \mathrm{bcm}$ by 2020 (European Commission 2006a: 25). Another EU-backed project is the 'Trans-Caspian Gas Pipeline' that is planned to bypass Russia by going along the Caspian seabed before connecting with the Nabucco pipeline. It would bring natural gas from Central Asia "via the Southern Caucasus or Iran and Turkey to the EU, the Western Balkans and other partner countries linked to the 'European Neighbourhood Policy" (European Commission 2006a: 46-47). These projects are designed to serve two functions at the same time: on the one hand, they will bring gas from Central Asia, thereby diversifying the EU's sources of energy, while, on the other hand, they will not cross Russian

\footnotetext{
${ }^{6}$ trillion cubic metres $(\mathrm{tcm})$
}

${ }^{7}$ billion cubic metres (bcm) 
territory, thereby diversifying transit routes. ${ }^{8}$ The EU's intentions to diversify energy supply, with the help of Central Asian resources, are viewed in Russia with increasing suspicion and regarded to be an infringement on Russian geo-political and geo-economic interests in the region.

The geo-economic interests, in particular, are significant because energy-trade plays an extremely important role in Russia's economic development. In 2005 the energy sector represented $20 \%$ of the country's GDP while in 2007 it generated around $64 \%$ of its export revenues (House of Lords 2008: 45). Despite the Kremlin's recurrent declarations of the need to diversify Russia's economy, it is still dependent on oil and gas production (see Hanson 2007). Moreover, according to the Energy Strategy of the Russian Federation for the Period until 2020 (adopted in 2003), Russia's energy resources are also "an instrument of domestic and foreign policies" (Ministry of Industry and Energy of the Russian Federation 2003). The document states that "the country's role on the world energy markets largely determines its geopolitical influence" (Ministry of Industry and Energy of the Russian Federation 2003). The exceptional significance attached to energy resources by the Kremlin goes some way towards explaining why Russian elites are increasingly wary of attempts by other international actors to operate within this sphere and consider such attempts as an infringement on Russian interests.

The EU-backed diversification projects are regarded by Moscow as threatening to Russia's interests for a number of reasons. Firstly, the transit of Central Asian oil and gas through Russian territory, with the pipeline system being under state control, generates substantial revenues, and Moscow obviously does not want to lose this source of income. Moreover, Russian gas is more expensive than Turkmen gas, which is why the purchase and exportation of Turkmen gas to the EU is more profitable for Moscow in the short-term compared with developing new gas fields in Russia. In 2006 the quantity of gas exports from Turkmenistan and Uzbekistan going to/via Russia reached 51 bcm (Paramonov 2008: 1). Secondly, according to both Russian and western energy experts, the Russian energy industry shows signs of a possible energy deficit (see Milov 2007; Riley 2006). Although Russia has the largest proved gas reserves in the world, chronic underinvestment in the development of new gas fields and drying up of existing fields could lead to a situation where Russia will not be able to maintain the required level of export to the EU (Fredholm 2006: 12). Moreover, Russia also requires gas for its growing domestic market; for example, the increasing levels of domestic demand for gas makes it possible for Russia to export only around 30\% of its production (Svedberg 2007: p. 199). All this means that Russia increasingly needs to import gas from Turkmenistan to ensure that its commitments to its consumer EU member states are met (Svedberg 2007: 199). Thus, retaining control over the export of Central Asian energy to the EU is of utmost importance to Moscow.

With Nabucco and the Trans-Caspian projects being regarded as potentially damaging for Russia's interests, it is possible to take the view that recent measures by the Kremlin have been designed to undermine the feasibility of the EU-backed projects. For example, the struggle to secure access to Caspian gas resources reached a climax in May 2007, when Vladimir Putin signed a declaration with the leaders of Kazakhstan, Turkmenistan and Uzbekistan to (1) construct a Caspian pipeline that would go along the Caspian coast through the territories of Turkmenistan and Kazakhstan, and (2) up-grade the Central AsiaCentre pipeline (a remnant of Soviet pipeline infrastructure). According to the agreement between Russia, Turkmenistan and Kazakhstan signed in December 2007 as a result of the negotiations that followed the May declaration, the new pipeline will increase the existing capacity to export Turkmenistan's gas to Russia by $20 \mathrm{bcm}$.

Russia has also begun to implement its own diversification projects in an attempt to decrease its dependence on its traditional transit countries, such as Ukraine, which at present sees around $80 \%$ of Russia's gas exports transfer via its territory (Svedbergy 2007: 197). The

\footnotetext{
${ }^{8}$ Turkmen gas currently comes to the European market through Russia, with Russian state-owned company Gazprom being 'the single customer' (Paramonov and Strokov 2008: 5).
} 
'Nord Stream' and 'South Stream' projects are designed to bypass traditional transit countries for Russian gas exports to the EU and thus diversify transport routes. Nord Stream is an offshore natural gas pipeline which will go through the Baltic Sea, from Vyborg, Russia to Greifswald, Germany, from where gas could be transported onwards to a number of interested EU member states, reportedly including Denmark, the Netherlands, Belgium, the UK, and France. The pipeline will have a transport capacity of around $55 \mathrm{bcm}$ per year and is expected to be completed in 2011 (Nord Stream 2008). The South Stream pipeline will go under the Black Sea and will carry gas from Russia to Southeast and South European countries (Milov 2007a: 138) via Bulgaria, Serbia, Hungary, Slovakia and Austria.

Furthermore, the Kremlin has responded to the EU's declared intention to diversify energy imports with its own declaration of intent to diversify energy exports, thus reducing Russia's traditional focus to export the majority of its energy to the EU. According to Andrei Dement'ev, Russia's Deputy Minister for Industry and Energy, Russia will significantly diversify its energy exports by 2015 by increasing its supplies to the Asian markets by up to 15 per cent for oil and 25 per cent in the gas sector (Dement'ev 2007). Moreover, the Energy Strategy of the Russian Federation for the Period to 2030, which has been discussed by the Russian expert community for some time now (see Bushuev 2008; Delyagin 2008) and is expected to be published in the near future, envisages even more significant restructuring of Russian energy exports with increasing emphasis on energy supplies to China and other countries of the Asia-Pacific Region. The East Siberia-Pacific Ocean (ESPO) pipeline will bring up to 1.6 million barrels of crude oil per day from Siberia to Russia's Far East and then to China (RIA Novosti 2008). In addition, the Altai gas pipeline which will have a transport capacity of around $68 \mathrm{bcm}$ per year will go from West Siberia to the Xinjiang-Uyghur Autonomous Region in western China (Gazprom 2006). China is viewed as a very promising market for Russian hydrocarbons due to the geographic proximity of Russian oil and gas fields to the Russian/Chinese border and to the continuing growth of the Chinese economy which is accompanied by increasing energy demand. However, some Russian experts have voiced their doubts about the profitability of these projects as it is unlikely that China will be able to pay the same price that Russia receives from its exports to the EU (see Milov 2006).

Map 1 (see page 136) illustrates the diversification projects on the territory of the former Soviet Union as discussed above, including the existing pipelines and those that are still at the planning stage by both the EU and Russia. The competition for Central Asian energy resources between the two powers (as well as some other 'major' players such as the USA and China) has been compared to the Great Game of the $19^{\text {th }}$ Century - the rivalry between the Russian and British Empires for influence in the region (see Blank 1995; Rasizade 2005). Since energy diversification projects are at the heart of this renewed rivalry between Russia and 'the West', it could be argued, that we are witnessing the emergence of a Great Diversification Game. As a result of their clash of interests - both objective and perceived Russia and the EU are supporting a number of projects that compete for Central Asian resources and ultimately threaten to undermine each other.

\section{Russia Versus the EU in the 'Shared Neighbourhood'}

\section{Why is Russia so sensitive to the EU's diversification projects in the 'shared neighbourhood'?}

To answer this question, it is necessary to examine Russian perceptions of the EU's policies towards the post-Soviet area. Ever since the collapse of the Soviet Union, Russia's political elite has been wary of any attempts by other countries or international organisations to gain influence in the post-Soviet area. Even in the early 1990s, when Russia's political relations with the West were at a post-Cold War positive high, there remained a concern among some members of the Russian political elite that Russia should retain an important role and influence in its 'near abroad'. The 'Foreign Policy Concept of the Russian Federation' (1993) notes, for instance, that some countries might try to "replace Russia in the countries of its traditional influence under the disguise of intermediary and peace-keeping efforts" (Ministry 
Map 1: Russian Oil and Natural Gas at a glance

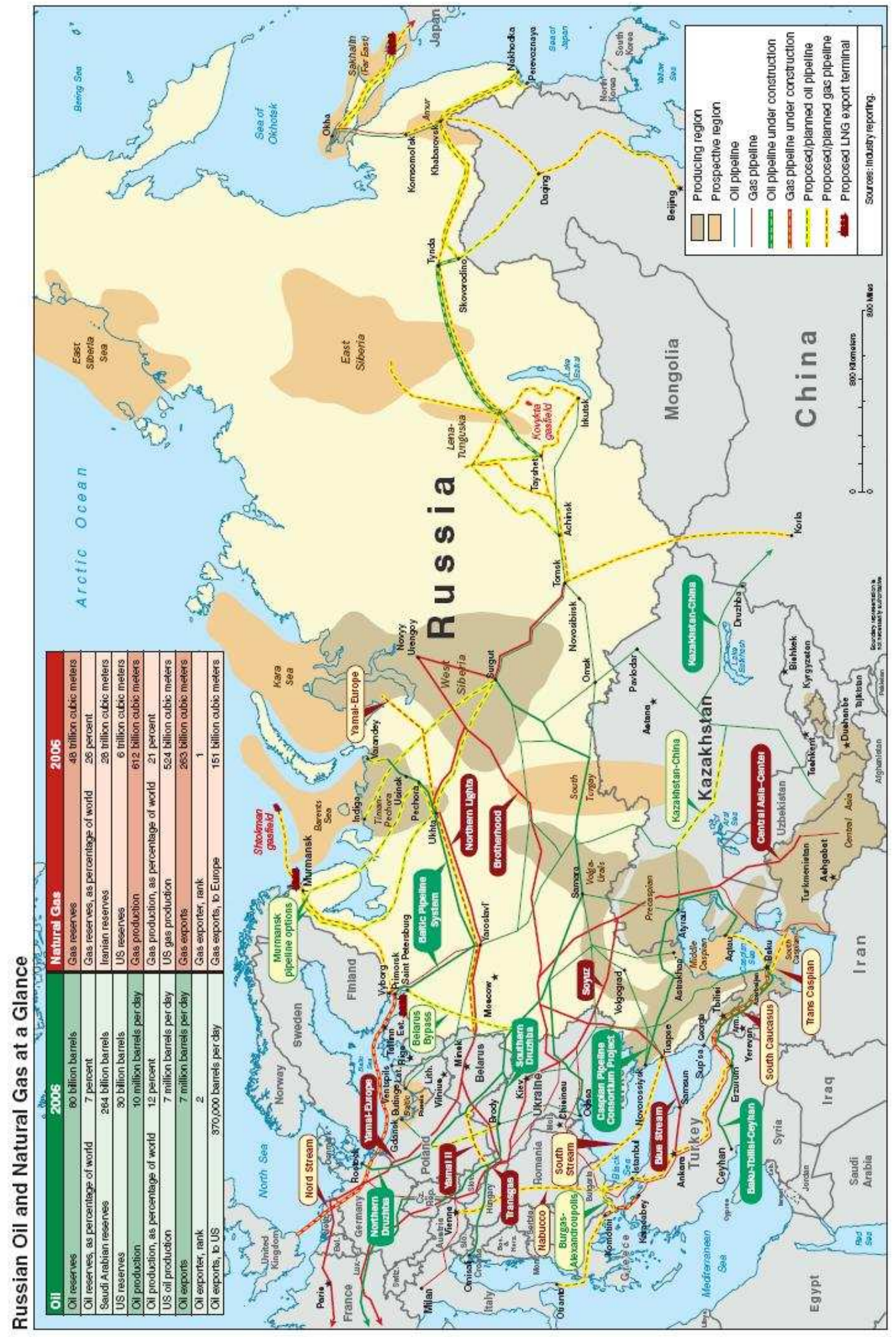

Source: Energy Information Administration 2007 
of Foreign Affairs of the Russian Federation 1993: 31). In this regard it was the United States and NATO that continued to be considered the more serious threat, while the European Union was not regarded as a threat in this respect. In particular, NATO's expansion in Central and Eastern Europe encountered fierce criticism from the Kremlin, whereas its reaction to EU enlargement was less negative, and on the whole not as intense (Allison 2006: 160).

The Orange Revolution in Ukraine at the end of 2004 was a turning point for Russia's attitude towards the EU's policy in the 'shared neighbourhood'. Poland and Lithuania both supported the pro-Western candidate, Viktor Yushchenko. Both of these countries, as new EU member states, used the EU as a platform or point of reference for the political aspirations of Yushchenko. Regardless of the fact that Lithuania and in particular Poland, as a neighbouring state to Ukraine, had legitimate regional interests in what was happening in Ukraine, Russia took the position that the EU (as a political bloc) was interfering in a specific Russian sphere of interest. For example, in the Russian mass media, the events in Kiev were constructed as a battle between the East - that is Russia and pro-Russian Ukrainians - and the West - the EU and the USA - which, it was argued, wanted to weaken Russia by "tearing off" its neighbour [Ukraine] (Pushkov 2004). This strengthened anti-Western elements in Russian public opinion, which in turn became more suspicious of the EU's intentions towards Ukraine and other CIS countries. However, it should be noted that the USA still remained the predominate threat within Russian political discourse. According to a public opinion survey conducted by the All-Russian Public Opinion Research Centre (VCIOM) in April 2005, 75 per cent of respondents in Russia expressed negative feelings towards the increased influence of the USA and the EU on the former territory of the Soviet Union (see Figure 1). Just over half of the respondents acknowledged that they felt apprehensive about this development, and almost a quarter described the increased influence as "unpleasant, but not too dangerous" (VCIOM 2005).

Figure 1: Attitudes towards increased influence of the US and EU in the area of the former Soviet Union, April 2005.

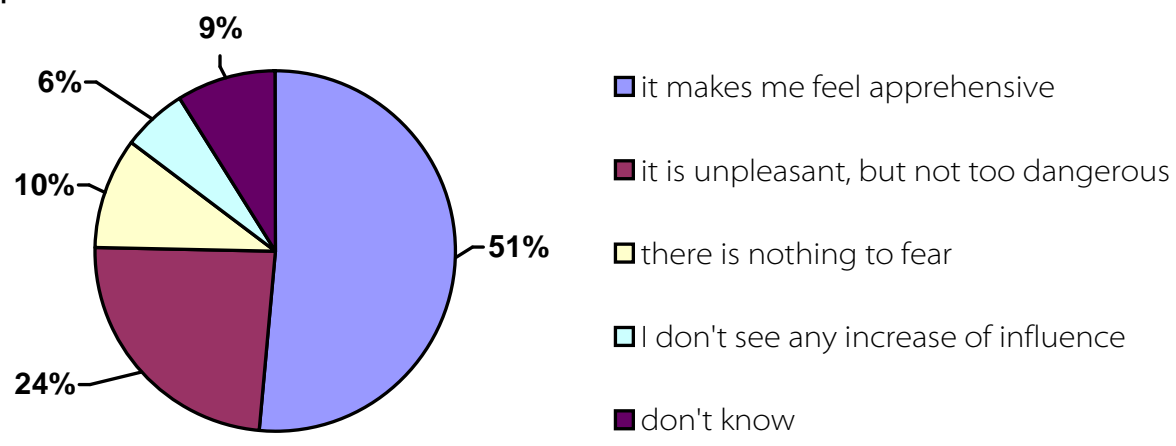

Source: VCIOM 2005

While the Western mass media featured many articles that accused Russia of pursuing 'neoimperial' ambitions in the post-Soviet area (see Applebaum 2004; The Independent 2008), in the Russian official discourse more emphasis was placed on the 'legitimacy' of Russia's interests in the CIS countries (Labetskaya 2008; Nezavisimya Gazeta 2006). At the same time, as Russian foreign policy was becoming more assertive, Russian high-ranking officials started to put increasing emphasis on the Kremlin's readiness to defend its interests in the region. As the then Minister of Foreign Affairs, Sergey Lavrov, argued in his speech to the State Duma in May 2005, "We do not want the CIS to turn into an area of rivalry with anyone. We do not claim to have a monopoly in this region, but we will not let anyone else have a monopoly here either" (RIA Novosti 2005). 
It should be mentioned that re-integration of the post-Soviet space has been high on Russia's foreign policy agenda since the disintegration of the Soviet Union (see Vinokurov 2007: 22). However, Moscow's approaches to integration have changed significantly over time. In the 1990s the Kremlin viewed the re-integration project within the Commonwealth of Independent States as the most important project of regional integration. Under Vladimir Putin's presidency, the ambition to integrate, or at least to cooperate closely, with some of the neighbours became more important (e.g. the 'Common Economic Space' - a project that is meant to foster the integration of the 'Big Four' - Russia, Ukraine, Kazakhstan and Belarus). The ambition to challenge the USA's hegemonic status and establish a multipolar world order is one of the driving forces of Russian foreign policy emphasised by the Russian President at the Security Conference in Munich in February 2007 (Putin 2007). It is argued that Russia needs to establish a dominant position in its own neighbourhood as a stepping stone towards claiming the status of an independent centre in a multi-polar world. As Russia's Minister for Industry and Energy, Viktor Khristenko (2004), pointed out in a recent article in Russia in Global Affairs, "Russia cannot compete with major global players like the EU, the Asia-Pacific countries or the United States alone. As part of a common economic space, Russia would be more confident in pursuing its interests, while relying on common resources". Demonstrating Russia's key role in the area serves also as "an important legitimising device" for the Kremlin, helping to persuade the electorate that Russia is indeed a great power (Anderman et al. 2007: 43).

\section{How do the Russian elites perceive the EU's Neighbourhood Policy?}

Although the ENP in Moscow's eyes is not considered to be as serious a danger as the NATO enlargement policy promoted by the USA (Zagorski 2005), it is still regarded as a formidable obstacle to Russia's integration projects. This is emphasised in a report by the Institute of Economics of the Russian Academy of Sciences and the National Investment Council (2007), which argues that the ENP "ties the neighbours to European programmes and projects", and, what is more, imposes on them requirements "to limit cooperation with Russia to the lowest level", (i.e. not to go further than a free trade area) (cited in Omel'chenko 2007). Thus, according to the report, the ENP is to be blamed for the apparent lack of success of the Common Economic Space (Omel'chenko 2007). Trenin (2005: 2), of the Moscow Carnegie Center, also contends that Russia sees the ENP as "too competitive with its own perceived interests in the common neighbourhood".

How do the Russian elites perceive the EU's vision of energy security and the planned diversification projects?

Moscow has been very sensitive to the on-going debate in the West over whether or not Russia is a 'reliable energy supplier'. To be regarded as a reliable supplier of energy to the European market is of great importance to Russia. In response to growing scepticism on the part of the EU, Russian authorities point out that Russia (and the Soviet Union previously) has been a reliable supplier of energy to Europe for over 30 years (RIA Novosti 2006). Of course, events such as the 2005-2006 Russian-Ukrainian gas dispute did little to help Russia's images, so it is understandable that Moscow considers it necessary to conduct a public relations campaign to improve Russia's image as a reliable energy supplier. As part of this campaign, Moscow has continuously stressed that it is the transit countries, especially Ukraine, that are to be blamed for any supply shortages (RIA Novosti 2007b). For Russia, the way that it conducts its relations with CIS countries should not be used as evidence of its approach and intentions towards relations with the EU and its member states. There is a fundamental difference in Moscow's approaches to its relations with the countries of the 'near' and 'far' abroad: while Russia's policies in the 'near abroad' are more coercive, its policies in the 'far' abroad tend to be more pragmatic and cooperative (Casier 2007: 82). Therefore, any suggestion that Russia will use energy as a geopolitical tool against the West is perceived by Moscow as unjustified. 


\section{What are the reasons for the EU's distrust of Russia as an energy supplier?}

There are several recurrent explanations in the dominant Russian discourse. Firstly, Russia's negative image is seen as being rooted in centuries-long 'Russophobia' which intensified in Europe with the strengthening of Russia's position in the world during Vladimir Putin's presidency (2000-2008). According to Alexander Murychev, first Vice-President of the Russian Council of Industrialists and Entrepreneurs (RSPP) "we [Russia] are too large, too big, our potential is too huge" (Voice of Russia 2007b). Secondly, diversification plans are perceived to be a product of anti-Russian sentiments within the new, EU member states that joined in 2004 and 2007 and which are trying to thrust their view on energy security on the old member states (Voice of Russia 2007a). The latter argument is especially popular, as it resonates with a number of other tensions in Russia's relations with Eastern European and Baltic countries.

Another popular narrative describes the EU's criticism of Russia's energy policy as 'psychological attacks' which are meant to weaken Russia's position and to defeat it in the geopolitical battle for energy resources. As Vladislav Belov, of the Institute of Europe at the Russian Academy of Sciences emphasised in an interview with 'Voice of Russia', portraying Russian oil and gas as the Kremlin's tools to apply pressure on the EU is "an attempt by certain Western politicians and the mass media to blackmail Russia by accusing it of blackmailing [the EU]" (Voice of Russia 2007c).

While Russia is seen in the dominant Russian discourse as a reliable supplier of energy to Europe, the EU's intentions and concern about the need to diversify energy sources and routes are often described by Russian officials and the mass media as paranoia, an idée fixe (Diev 2007). EU diversification projects are considered to be politically motivated, antiRussian and not based on purely economic calculations. One of the prevalent interpretations is that the EU is frightened by Russia's growing strength and assertiveness in the international arena, and is therefore keen to "depriv[e] Russia of one more trump card in its relations with the West" (Boldyrev 2007). Furthermore, successful implementation of the EU's diversification projects in Central Asia would have severe consequences for Russia in that it would lose transit revenues that it could invest in its own economic development. Therefore, from the Russian point of view, the EU's diversification plans are targeted not only against Russia's legitimate geopolitical interests, but also against the Russian economy.

Finally, some Russian commentators explain the EU's diversification drive as the result of Washington's attempts to coax the EU in the 'wrong' direction. This position is illustrated by Mikhail Leont'yev, the host of the popular analytical programme 'Odnako' ('However') on Russia's most influential television 'Channel One'. Leont'yev described the EU's planned pipeline projects that are designed to bypass Russia as a transit country as "not only unprofitable, but even dangerous" for the EU. According to Leont'yev, "America is deeply interested in Europe's lack of energy security because Europe is its main competitor. And the European leaders obediently meet at the summit where they discuss... what to tear off or to cut from themselves..." (Pervy kanal 2007). These arguments reinforce the vision of Russia as a 'besieged fortress', while emphasising Russia's reliability as a supplier and lambasting the EU's 'suspiciousness' as unjustified. They also encourage the growth of anti-Western sentiments in Russian society which have become more pronounced in recent years (see Shevtsova 2007).

It is clear that Russia maintains serious concerns about its position vis-à-vis the EU, and it could be argued that these concerns have also contributed to the Kremlin's unwillingness to ratify the Energy Charter Treaty (ECT) which it had signed in 1994. For Russia, the ECT's Transit Protocol would grant third parties access to Russia's transit infrastructure without necessarily offering anything in return'. The ECT is regarded as 'the West's' attempt to gain

\footnotetext{
${ }^{9}$ It should not be forgotten that Norway, an important supplier of oil and gas to the European Union, has also signed, but not ratified the ECT.
} 
access to Russia's energy resources and transit routes. Vladimir Putin (2006) explained the Kremlin's position on this in an interview with the German television channel ZDF:

\begin{abstract}
We ask our partners: "Very well, we shall give you access to this infrastructure and where will you allow us access?" And they answer: "We will reciprocate". And I ask you: "Where are these deposits? Where are the huge gas pipelines and infrastructure like the ones we have?" Our partners do not have such an infrastructure. For that reason signing and ratifying the additional protocols with Russia is a unilateral decision, and we shall not accept unilateral decisions.
\end{abstract}

In this narrative there is a clear opposition between (1) 'our resources', which refers to those resources belonging to Russia and which no one but Russia has the right to claim and (2) 'them', which refers to the 'West' and those who are eager to deprive Russia of its natural advantages. The emphasis on 'our interests' is especially pronounced in contemporary Russian discourse. This can be explained as a direct consequence of Russia's perceived weakness in the 1990s when the Kremlin, as many in Russia argue, compromised Russia's positions on many issues of strategic importance to the country (see Lyne 2008: 91).

In response to the EU's attempts to decrease its dependence on Russian energy, the Kremlin is actively trying to shift the focus of attention away from the diversification of supply sources and towards the diversification of supply routes. The 'Nord Stream' and 'South Stream' projects are, in this context, presented as Russia's own contribution to EU energy security. These two pipelines cross the Baltic and Black Seas respectively and will enable Gazprom to supply gas to EU member states directly, bypassing the traditional transit countries of Ukraine, Belarus and Poland. At the same time Moscow is placing more and more emphasis on negotiating alternative projects with Central Asian countries which will then compete with the EU's diversification projects in the region, depriving them of the necessary supplies of gas and oil, thus rendering these EU projects unprofitable.

\title{
Central Asian Resources as a 'Trump Card'
}

The growing interest and engagement of the EU in the Central Asian countries came at a time when Russia started to conduct a more pro-active policy in the region after having significantly recovered from its considerable weakness of the 1990s. A statement by Deputy Minister for Industry and Energy, Andrei Reus (2007), to foreign journalists in May 2007 illustrates this view: "Central Asia for us is one of the most important directions of Russia's energy policy". The EU's diversification projects in Central Asia are considered as a real threat to Russia's interests in these countries. Larsson (2006: 5) argues that "Russia has strategic priorities to keep its influence over the CIS and its energy policy is one of the means used for this reason".

In addition to these 'objective' factors, there are also a number of perceived threats that the EU's cooperation with Central Asian countries create for Russia's interests. Firstly, successful implementation of diversification projects would strengthen the geo-political positions of transit countries. This, in turn, would make it more difficult for Russia to play a leading role in the region. Secondly, in the context of mounting tensions between Russia and the EU, Moscow is interested in maintaining a high level of interdependence with EU member states in terms of 'energy trade'. It could therefore be argued that Moscow sees this interdependence not so much as a tool to exert pressure on the EU, but rather as an instrument of 'self-defence' which would not only guarantee the EU's non-interference in Russian domestic politics, but ensure also that Russia's interests in the international arena are not neglected. Russia is therefore keen to prevent any reduction of the EU's energy dependence on Russia. Finally, the Kremlin's successes or failures in its attempts to maintain Russia's influence in the region are of great symbolic significance for the Russian electorate. As the Russian authorities are trying to promote the image of Russia as a 'great power' among the domestic Russian populous, the EU's cooperation with the CIS countries would 
challenge this vision, demonstrating instead that Russia is losing a geopolitical game of vital importance in the 'near abroad'.

In this context, the signature of a declaration by the Russian President and the leaders of Kazakhstan, Turkmenistan and Uzbekistan on the construction of a Caspian pipeline in May 2007 impacted significantly on the vision of Russia's political position in the Caspian region vis-à-vis the EU. Firstly, the symbolic importance of President Putin's meeting with the Central Asian leaders to 'sign' the Caspian declaration cannot be overstated; the meeting took place on 12 May - one day after the leaders of Azerbaijan, Georgia, Ukraine, Poland and Lithuania had met in Krakow to 'discuss' diversification projects that would bring Central Asian hydrocarbons to European countries, bypassing Russia. One particular project discussed was the extension of Ukraine's Odessa-Brody oil pipeline that would bring mainly Kazakh oil from the Caspian Sea via Poland to other EU member states. The President of Turkmenistan did not attend this summit and Kazakhstan was represented by the Deputy Minister for Energy and Natural Resources (not the President). These facts were presented in the Russian mass media as a sign of the pro-Russian choice made by the Presidents of Turkmenistan and Kazakhstan. Moreover, President Nazarbayev's 'loyalty' to Russia was particularly emphasised in the Russian discourse. His statement that "Kazakhstan is committed to transporting most of its oil, if not all of it, across Russian territory" (cited in Rubanov 2007) was quoted in numerous mass media outlets as an illustration of his 'proRussian' choice, which strengthened the image of Kazakhstan as Russia's ally, and consequently reinforced the image of Russia as a re-emerging great power in the post-Soviet area.

Secondly, although some Russian experts expressed their doubts about whether signing the declaration would lead to a substantial strengthening of Russia's position in relation to the EU in the long-term (see Milov 2007b), the dominant discourse in the Russian mass media and in statements by Russian politicians was that of a real 'geopolitical victory' (see Kolesnikov 2007). Konstantin Simonov, head of the Foundation of National Energy Security, illustrated this when he commented that "Russia has demonstrated to the EU: guys, we've got good positions in Central Asia" (Rubanov 2007). What is more, in many Russian mass media publications Russia's victory was presented as somewhat final and as such had left no further alternatives for the EU other than to rely on the Russian transit system for its supplies of oil and gas from the region (Kolesnikov 2007; Yunanov 2007). It was suggested that as a result of the deal, the EU would have to reconsider its critical rhetoric towards Russia; for example, according to the newspaper Moskovskie Novosti "instead of helpless 'blockade diplomacy' some ambitious European players should radically change the tonality of their dialogue with Moscow" (Yunanov 2007).

Thirdly, making the EU's diversification projects potentially unprofitable, or, to put it more bluntly, blocking the establishment of an 'anti-Russian alliance of European countries' was regarded to be the main geopolitical goal that the Kremlin had achieved with its agreement with the Central Asian leaders (RIA Novosti 2007c). Some Russian commentators hurried to express their doubts about the feasibility of the Trans-Caspian project and the Nabucco project now that Moscow had secured an agreement with the Central Asian leaders, emphasising that "they do not have any resource base now" (Rubanov 2007). One of the most popular narratives at that time was that the agreement demonstrated how "the [Russian backed] Caspian pipeline [had] defeated the [EU backed] Trans-Caspian one" (Kolesnikov 2007).

Moreover, when discussing the two rival projects in the Caspian region, Russian politicians and commentators emphasised the economic advantages of Russia's project while at the same time emphasising the political (and anti-Russian) character of the EU's Trans-Caspian pipeline. In the opinion of Viktor Khristenko, Russia's Minister for Industry and Energy, "the existing risks [of the Trans-Caspian project]- technical, legal, environmental - are so big that it is impossible to find an investor unless it is a political project and it does not matter what the pipeline will be filled with" (RIA Novosti 2007a). On the contrary, the Caspian pipeline was 
presented as a profitable project, with a clearly defined resource base and a well calculated budget. According to Deputy Minister for Foreign Affairs, Andrei Denisov, in an interview with the newspaper Vremya Novostei (cited in Labetskaya 2008) questions were also raised about the [real] reason for [constructing the Trans-Caspian pipeline] when "there are cheaper supply routes". There are obvious similarities between the arguments used by Russia and the $\mathrm{EU}$ in favour of or against these two projects. These reflect similar arguments made about the Russian-German 'Nord Stream' pipeline project. In both cases cost efficiency, technical difficulties and environmental risks have been used to highlight the political nature of the projects with Moscow resorting to the same arguments against the EU's rival project in the Caspian region, as some EU member states (especially Poland and the Baltic states) have used to protest against the implementation of the Nord Stream project.

\section{What are Russia's perceived advantages over the EU in this 'diversification game'?}

In addition to the 'objective' factors of the existing structural interdependence of the former Soviet Republics - much of the energy infrastructure of the former USSR is still in place - a number of more 'subjective' advantages have been emphasised in the Russian discourse. Firstly, Russian politicians and experts underline Moscow's policy of 'non-interference' in the domestic policies of the states in the 'near abroad'; unlike the EU, Russia would not tie energy cooperation to the promotion of democracy in these countries (Rubanov 2007). Secondly, Russia finds it much easier than its European counterparts to work in the context of political uncertainty in Central Asia because it is more familiar with the political culture of the region. Another factor often mentioned in this context is Moscow's vision of Iran as a 'tactical ally' in its competition with the EU's rival projects considering that the future of the Trans-Caspian project is, in no small part, dependent on resolution of the legal status of the Caspian Sea. ${ }^{10}$ Iran as a littoral state has a say in that matter: "while there are no joint decisions concerning the status of the Caspian Sea, Iran - unfriendly to the West - is [Russia's] key ally" (Boldyrev 2007).

Privileged access to Central Asian energy resources is viewed by Russia as a trump card in terms of its relations with the EU: if secured, it would not only help Russia to overcome the difficulties it is experiencing with its own domestic energy production, but it would also strengthen Russia's geo-political position vis-à-vis 'the West'. Since Moscow perceives the EU's diversification projects in Central Asia as essentially 'anti-Russian', it is argued that it is in Russia's national interests to prevent the successful implementation of these projects.

\section{Is the Game Worth the Candle?}

How do perceptions held by the Russian elite regarding the EU-backed diversification projects and their own visions of Russia's advantages in the competition with the EU impact Russia's energy policy in the region and Russia's relationship with the EU? Although Moscow sees energy as an instrument that could help Russia reclaim its great power status, it has, as yet, failed to developed a coherent energy strategy (see Monaghan 2007). At the turn of the century Russia's policy in the Caspian became more pragmatic, particularly when compared to the policies pursued during the 1990s when strategic considerations often gave way to economic ones (Bahgat 2002). At the end of Vladimir Putin's first presidential term, and even more so during his second term, Russian foreign policy became overall much more assertive, with more emphasis being placed on the need to pursue strategic goals (Trenin 2006). In part, this is linked with a reassertion of the vision of Russia as a great power - something which

\footnotetext{
${ }^{10}$ Azerbaijan, Russia, Kazakhstan, Turkmenistan and Iran have not agreed upon the legal status of the Caspian Sea. The question whether the Caspian is a sea or a lake is of utmost importance since these two options would mean different approaches to dividing the Caspian Sea waters and mineral resources between the littoral states (see O'Lear 2004). Consequently, any off-shore pipeline projects can be implemented only after all the five states have agreed on the Sea's status (Energy Information Administration 2002).
} 
has always been an integral part of Russia's identity (Feklyunina 2008). This was reflected in most of the foreign policy statements of Russian high-ranking officials and especially in the Russian mass media (see Egorova 2007; Radzokhovsky 2007). According to the great power discourse that came to dominate Russian political debates, Moscow should defend its legitimate interests in the 'near abroad' and endeavour to reclaim its special status by "promoting a form of soft and nuanced hegemony" (Allison 2004: 278). At the same time, it should be careful to resist other international actors' attempts to increase their influence in the region. The EU's diversification projects in the shared neighbourhood were therefore perceived as infringements on Russia's geopolitical interests.

Russia's perceived revival as a great power was met with widespread approval by the Russian electorate, and significantly increased Vladimir Putin's standing in the country. Consequently the Kremlin is keen to maintain and promote the image of Russia's success diplomacy (or 'victories') in the 'near abroad'. As a consequence, energy projects backed by the EU have become more politicised, and any success by the EU in its diversification projects would be regarded as a terrible 'defeat' for Moscow in the geopolitical battle with the West. The Kremlin's sensitivity to this issue became especially pronounced at the end of Vladimir Putin's second term in office when, in the run up to the Russian presidential elections of 2008, it became extremely important for the Russian authorities to demonstrate their readiness to defend Russia's interests against the 'West', including the EU.

Divergent perceptions of what constitutes 'energy security' held by Moscow and Brussels contribute to a proclivity to interpret each other's actions as a 'threat' to their national security. The EU, as an energy importer, is preoccupied with security of supply: it is wary of the increasing dependence on Russia and sees diversification of supply sources and routes as a way to minimise security risks. For Moscow, on the other hand, energy security means, first and foremost, security of energy demand. The Kremlin is therefore interested in securing long-term contracts with energy consumers, and is keen to minimise dependence on potentially unreliable transit countries such as Ukraine. These divergent visions of energy security held by Moscow and Brussels have led them to see diversification of energy suppliers and supply routes (in case of the EU) and of energy consumers and the reduction of reliance on transit countries (in the case of Russia) as a possible way to enhance their security. Their respective diversification projects are, however, perceived by the other side as a threat which undermines trust in their bilateral relationship. Under these conditions, a vicious circle has been created in the form of a mutual energy security dilemma, with both actors feeling increasingly threatened by each other's intentions to diversify their energy relations with third countries in an attempt to enhance their respective security situation. Any actions taken are consequently regarded as being targeted against each other. This contributes to a growing instability in their relations, resulting in a 'diversification race' (Goets 2007).

Considering that the EU's diversification projects in the 'shared neighbourhood' are seen by Moscow as anti-Russian, with a potential to reinforce already existing tensions in the EURussian relationship, how significant can the contribution of Central Asian states to the EU's energy security really be? Is the game 'worth the candle' for the EU? Although these countries are considered to be rich in energy resources, there is no reliable data on the exact size of their proved resources. Estimates suggest that Kazakhstan has 39.8 thousand million barrels of proved oil reserves (equating to 3.2 per cent of world reserves). As for proved natural gas reserves, Kazakhstan is estimated to have around 1.9 trillion cubic metres (1.1 per cent of world reserves) and Turkmenistan is estimated to possess around 2.67 trillion cubic metres (1.5 per cent) while Uzbekistan's potential is estimated to be around 1.74 trillion cubic metres (1.0 per cent of world reserves) (British Petroleum 2008)

There is a significant disparity between the assessments provided by industry experts and academic institutions on the one hand, and those by the United States government on the other hand, which has led some analysts to speak of "an orchestrated effort by Washington to exaggerate the significance of the region's hydrocarbon wealth" (Bahgat 2002: 310). In this context it is argued that one of the main reasons for Washington's "disproportionate 
interest" in Central Asia was its determination to prevent Russia from reclaiming its influence in the region (Bahgat 2002: 315). In the 1990s, a period during which the EU was not engaged in the competition for Central Asian hydrocarbons, with the leading role played by the USA, some experts cautioned against the danger of over-estimating the significance of the region's resources. Their argument was that this could "rais[e] the risk of unnecessary contention with other actors, particularly Russia and Iran" (Myers Jaffe and Manning 98-99: 112).

The EU's growing interest in Central Asia a decade later and its vision of the region's energy resources as a panacea to long-term energy security seem to run the same risk. While Central Asian states keep expressing their interest in the EU-backed diversification projects, it is not clear if they possess sufficient resources to fulfil their contractual obligations to Russia and at the same time supply the European market. Turkmenistan's President Gurbanguly Berdymukhammedov, for instance, spoke of his country's readiness to consider various projects, including the Trans-Caspian pipeline, even after signing the declaration on the construction of the joint Caspian pipeline project with Kazakhstan and Russia (see Melikova 2007). Turkmenistan's actual ability to supply natural gas for the Trans-Caspian pipeline was called into question by some experts when it became public that according to the agreement concluded in December 2007 between Turkmenistan, Russia and Kazakhstan, the volume of gas to be exported through the Caspian pipeline would be only 20 billion cubic metres instead of the 30 billion cubic metres that had been agreed during the May negotiations (Tomberg 2007).

On the one hand, this reduction in supply volume could confirm Turkmenistan's intention to continue negotiations over diversification projects with the EU as it can be suggested that Turkmenistan intends to export less gas to Russia in order to retain sufficient supplies for the Trans-Caspian pipeline. A contrasting interpretation is that Berdymukhammedov is using the possible participation of Turkmenistan in the rival Trans-Caspian project as an instrument to put pressure on the Kremlin, with the aim to secure more favourable terms for its exports to Russia. If the latter is true, the EU's diversification project in the Caspian region can hardly be regarded as a solution to its energy supply dilemma if it is lacking a confirmed and proven resource base. At the same time, the EU's diversification project increases tensions in its already rather strained relations with Russia, thereby further contributing to potential energy supply problems. This creates a real obstacle to the EU's success in this 'Great Diversification Game'.

\section{Conclusion}

Following Moscow's dispute with Ukraine over gas prices and overdue payments in 20052006 , the problem of energy supply security has risen high on the agenda of the political elites, both in EU member states as well as in discussions in Brussels and in Russia. While recognising the importance of the problem, Brussels and Moscow, have contrasting visions of what constitutes 'energy security': while the former focuses on the security of supply, the latter is preoccupied with the security of demand. Increasingly wary of its dependence on Russian gas, the EU views the diversification of energy supply sources and transportation routes as a possible solution to the problem, although this view is not necessarily shared by all of its member states. In order to enhance its security, the EU has been expanding its cooperation with the Central Asian countries, culminating in the launch of a 'Central Asia Strategy' in 2007. The Kremlin, on the other hand, is extremely sensitive to the EU's attempts at strengthening its ties with the ex-Soviet republics, as it considers Central Asia to be a sphere of Russian 'legitimate interest'. Thus, the EU's diversification projects in the region are perceived by Moscow as a threat to Russia's national interests.

The vision of Russia as a 'great power' became very salient in Russia's dominant discourse during the 'Putin era', and the EU's energy projects in the 'common neighbourhood' have become perceived as 'anti-Russian' in nature and had a pronounced effect on Moscow's 
vision of Russia's national interests. The Kremlin considers it necessary to prevent the EU from gaining influence in the Central Asian states. Russian policies in the 'near abroad' have, as a result, become more pro-active, and the conclusion of agreements with Turkmenistan and Kazakhstan to construct a Caspian pipeline that would rival the EU's planned pipeline project in the region has been presented in the dominant Russian discourse as Russia's 'victory' over the EU, and the West in general, in their 'geopolitical battle' for the Central Asian energy resources.

Because Moscow regards the EU-backed diversification projects in the Caspian region as essentially 'anti-Russian' they are perceived as posing a real threat to its own energy security. In an attempt to strengthen the security of demand, it has therefore resorted to declarations about its intentions to diversify its energy exports, with more gas and oil being directed towards the Asian markets. The EU and Russia are therefore supporting projects that are in direct competition with each other, which has resulted in a 'diversification race'. This rivalry over the Central Asian hydrocarbons not only undermines mutual trust in the EU-Russian relationship but it also makes both their diversification projects less profitable. The lack of reliable data on the size of proven Central Asian energy resources further complicates the situation, as it is not clear whether these countries will be able to fulfil their contractual obligations to both Russia and the EU countries, should the EU-backed diversification projects actually be implemented.

\section{References}

Allison, R. (2004). 'Strategic Reassertion in Russia's Central Asia Policy', International Affairs, 2, pp. 277-293.

Allison, R. (2006). '"Russia in Europe" or "Russia and Europe"', in R. Allison, M. Light and S. White (eds.), Putin's Russia and the Enlarged Europe. London: Chatham House.

Anderman, K., Frisell, E.H., and Pallin, C.V. (2007). Russia-EU External Security Relations: Russian Policy and Perceptions. Stockholm: Swedish Defence Research Agency.

Applebaum, A. (2004). 'Beneath the Skin, It's the Same Old Russian Bear', The Times, 15 March.

Averre, D. (2005). 'Russia and the European Union: Convergence or Divergence?', European Security, 14 (2), pp. 175-202.

Bahgat, G. (2002). 'Pipeline Diplomacy: The Geopolitics of the Caspian Sea Region', International Studies Perspectives, 3, pp. 310-327.

Blank, S. (1995). 'Energy, Economics and Security in Central Asia: Russia and Its Rivals', Central Asian Survey, 14 (3), pp. 373-406.

Boldyrev, Y. (2007). 'Kogda interesy protivopolozhny', Literaturnaya gazeta, 23 May, p. 2.

British Petroleum [BP] (2008). 2008 Annual Statistical Review of World Energy. British Petroleum.

Bushuev, V. (2008). 'Ideologiya energeticheskoi strategii', Neftegazovaya vertikal, 3.

Casier, T. (2007). 'The Clash of Integration Processes? The Shadow Effect of the Enlarged EU on its Eastern Neighbours', in K. Malfliet, L. Verpoest and E. Vinokurov (eds), The CIS, the EU and Russia: The Challenges of Integration. New York: Palgrave Macmillan.

Council of the European Union (2007) 'European Union and Central Asia: Strategy for a New Partnership', available at:

http://www.consilium.eu.int/uedocs/cmsUpload/EU CtrlAsia EN-RU.pdf, accessed 28 February 2008.

Delyagin, M. (2008). 'Kakaya energeticheskaya strategiya nuzhna Rossii?', Neftegazovaya vertikal, 3.

Dement'ev, A. (2007). 'Osnovnye elementy energeticheskoi strategii Rossii: Doklad zamestitelya Ministra promyshlennosti i energetiki RF Andreya Dementyeva na 11 
ezhegodnoi konferentsii investorov 'Renessans Kapital', 18 June 2007', available at: , accessed 7 September 2007.

Diev, A. (2007). 'Evropu manit vostok', Krasnaya zvezda, 11 July, p. 9.

Egorova, O. (2007). 'Boris Gryzlov: "My sokhranim za Putinym status natsionalnogo lidera", Izvestiya, 8 November, p. 3.

Energy Information Administration (2002) 'Caspian Sea Region: Regional Conflicts', available at: http://www.eia.doe.gov/cabs/caspconf.html, accessed 4 July 2008.

Energy Information Administration (2007). 'Russian Oil and Natural Gas at a Glance', available: http://www.eia.doe.gov/cabs/Russia/images/Russian\%20Energy\%20at\%20a\%20Glan ce\%202007.pdf, accessed 25 June 2008.

European Commission (2004). 'European Neighbourhood Policy', Strategy Paper, COM(2004) 373 final.

European Commission (2006a). 'A European Strategy for Sustainable, Competitive and Secure Energy', Green Paper, COM (2006) 105 final.

European Commission (2006b). 'An External Policy to Serve Europe's Energy Interests', Paper from Commission/SG/HR for the European Council, S160/06.

European Commission (2006c). 'Communication from the Commission to the Council and the European Parliament on Strengthening the European Neighbourhood Policy', $\operatorname{COM}(2006) 726$ final.

European Commission (2006d). 'EU/Azerbaijan Action Plan', available at: http://ec.europa.eu/world/enp/pdf/action plans/azerbaijan enp ap final en.pdf, accessed 30 June 2008.

Feklyunina, V. (2008). 'Battle for Perceptions: Projecting Russia in the West', Europe-Asia Studies, 60 (4), June, pp. 605-629.

Fredholm, M. (2006). Gazprom in Crisis. Swindon: Conflict Studies Research Centre.

Gazprom (2006). 'Altai Project', available at: http://www.gazprom.ru/eng/articles/article22202.shtml, accessed 30 June 2008.

Gachechiladze, R. (2002). 'Geopolitics in the South Caucasus: Local and External Players', Geopolitics, 7, pp. 113-138.

Goldthau, A. (2008) 'Russia's energy weapon is a fiction', Europe's World, Spring 2008, available at: http://www.europesworld.org/, last accessed 5 July 2008.

Götz, R. (2006). 'Das Treffen von Lahti: Wie weiter mit der Energiepartnerschaft?', Russland Analysen, 116, pp. 2-5.

Götz, R. (2007) 'Zentralasiatische Energieexporte: Zwischen russischer Dominanz, Diversifizierungsplänen der EU und neuen Märkten in Asien', Russlansanalysen, 137, pp. $2-6$.

Hanson, P. (2007). 'The Russian Economic Puzzle: Going Forwards, Backwards or Sideways?', International Affairs, 85 (5), pp. 869-889.

House of Lords (2008). The European Union and Russia. 14th Report, European Union Committee, London: Stationery Office.

International Energy Agency [IEA] (2004). World Energy Outlook 2004. International Energy Agency.

Khristenko, V. (2004). 'Making Headway to Integration', Russia in Global Affairs, 1.

Kolesnikov, A. (2007). 'Vladimir Putin povel kolleg posukhu', Kommersant, 12 May.

Labetskaya, K. (2008). 'Klyuchevye interesy Rossii - na prostranstve SNG', Vremya novostei, 8 February, p. 5.

Larsson, R.L. (2006) 'Russia's Energy Policy: Security Dimensions and Russia's Reliability as an Energy Supplier', March, FOI-R 1934-SE, Stockholm: Swedish Defence Research Agency, available at: http://www2.foi.se/rapp/foir1934.pdf, last accessed 20 March 2008.

Lyne, R. (2008). 'Russia and the West: Is Confrontation Inevitable?', Russia in Global Affairs, 1, pp. 86-102.

Malfliet, K., Verpoest, L. and Vinokurov, E. (eds) (2007). The CIS, the EU and Russia: The Challenges of Integration. New York: Palgrave Macmillan.

Melikova, N. (2007). 'Putin uvel turkmenskii gaz', Nezavisimaya gazeta, 14 May, p. 1.

Milov, V. (2006). 'How Sustainable is Russia's Future as an Energy Superpower?', Carnegie Endowment for International Peace, available at: 
http://www.carnegieendowment.org/events/index.cfm?fa=eventDetail\&id=860, last accessed 30 June 2008.

Milov, V. (2007a). 'Russia-EU Energy Dialog: Filling a Vacuum', Russia in Global Affairs, 4, pp. $132-142$.

Milov, V. (2007b). 'The Great Uncertainty: Russian-Central Asian Energy Relations, 13 July 2007', Carnegie Endowment for International Peace, available at:

http://www.carnegieendowment.org/events/index.cfm?fa=eventDetail\&id=1013\&pro $\mathrm{g}=\mathrm{zru}$, accessed 20 September 2007.

Ministry of Foreign Affairs of the Russian Federation (1993) 'Kontseptsiya vneshnei politiki Rossiiskoi Federatsii' in T.A. Shakleina (ed) (2002). Vneshnyaya politika i bezopasnost' sovremennoi Rossii, 1991-2002. Moscow: Rosspen.

Ministry of Industry and Energy of the Russian Federation (2003). 'Energeticheskaya strategiya Rossiiskoi Federatsii na period do 2020 goda', available at: http://www.minprom.gov.ru/docs/strateg/1, accessed 10 September 2007.

Monaghan, A. (2007). Russia and the Security of Europe's Energy Supplies: Security in Diversity? Swindon: Conflict Studies Research Centre.

Myers Jaffe, A. and Manning, R.A. (1998-99). 'The Myth of the Caspian 'Great Game': The Real Geopolitics of Energy', Survival, 40 (4), pp. 112-29.

Nezavisimya Gazeta (2006). 'Druzhit protiv Moskvy: Izbiratelnoe partnerstvo Zapada mozhet polozhit konets nadezhdam Rossii stat polnotsennoi chastiu tsivilizovannogo mira', 14 April, p. 10.

Nord Stream (2008). 'Nord Stream AG Project', available at: http://www.nordstream.com/en/project.html, last accessed 30 June 2008.

Olcott, M. (2004). The Energy Dimension in Russian Global Strategy. The James A. Baker III Institute for Public Policy of Rice University.

O'Lear, S. (2004). 'Resources and conflict in the Caspian Sea', Geopolitics, 9 (1), pp. 161-186.

Omel'chenko, S. (2007). 'Na pereput'ye', Ekonomika i zhizn', 12 May, p. 4.

Paramonov, V. (2008). The Future Supply Of Gas From Central Asia To Russia: An Expert Assessment. Swindon: Conflict Studies Research Centre.

Paramonov, V. and Strokov, A. (2008). Russia-Central Asia: Existing and Potential Oil and Gas Trade. Swindon: Conflict Studies Research Centre.

Pervy kanal (2007). 'Analiticheskaya programma "Odnako" s Mikhailom Leontievym', 16 May, available at: http://www.1tv.ru/owa/win/ort6 main.main?p news title id=102770, accessed 30 June 2008.

Pushkov, A. (2004). 'Ukrainu khotyat ne razdelit, a otorvat ot Rossii', Trud, 1 December, p. 4.

Putin, V. (2006). 'Interview with ZDF Television Channel (Germany), 13 July', available at: http://www.kremlin.ru/eng/speeches/2006/07/13/1416 type82916 108575.shtml, accessed 7 September 2007.

Putin, V. (2007). 'Speech and the Following Discussion at the Munich Conference on Security Policy', 10 February, available at:

http://www.kremlin.ru/eng/speeches/2007/02/10/0138 type82912type82914type82 917type84779 118123.shtml, accessed 30 June 2008.

Radzikhovsky, L. (2007). 'Voina i mir s Zapadom', Rossiiskaya Gazeta, 13 November, p. 3.

Rasizade, A. (2005). 'The Great Game of Caspian Energy: Ambitions and Realities', Journal of Southern Europe and the Balkans, 7 (1), pp. 1-17.

Reus, A. (2007). 'Doklad na brifinge dlya inostrannykh zhurnalistov v RIA Novosti, 8 May 2007', available at: http://www.minprom.gov.ru/activity/energy/appearance/30, accessed 11 September 2007.

RIA Novosti (2005). 'Lavrov: Zapad ponimaet, chto SNG ne zona voiny s Rossiei', 12 May.

RIA Novosti (2006). 'Ukraina uzhe otobrala $550 \mathrm{mln}$ kubov gaza, prednaznachennogo dlya Evropy', 3 February.

RIA Novosti (2007a). 'Khristenko skepticheski otsenivaet proekt transkaspiiskogo truboprovoda', 12 May.

RIA Novosti (2007b). 'Rossiya stremitsya k torgovle energonositelyami bez posrednikov Lavrov', 13 December.

RIA Novosti (2007c). 'Soyuz troikh na gazovom marshrute', 15 May.

RIA Novosti (2008). 'Russia, China Close to Deal on ESPO Oil Pipeline Branch', 22 May. 
Riley, A. (2006). 'The Coming of the Russian Gas Deficit: Consequences and Solutions', CEPS Policy Brief, 116. Brussels: Centre for European Policy Studies.

Rubanov, I. (2007). 'Ne po pravu sily', Ekspert, 21 May, pp. 21-28.

Saivetz, C. (2000). 'Caspian Geopolitics: The View from Moscow', The Brown Journal of World Affairs, VII (2), pp. 53-61.

Shevtsova, L. (2007). 'Anti-Westernism as the New National Idea', The Moscow Times, 7 August.

Stulberg, A. (2005). 'Moving Beyond the Great Game: The Geoeconomics of Russia's Influence in the Caspian Energy Bonanza', Geopolitics, 10, pp. 1-25.

Svedberg, M. (2007). 'Energy in Eurasia: the Dependency Game', Transition Studies Review, 14 (1), pp. 195-202.

The Independent (2008). 'Russia is acting like a colonial bully', 2 May.

Tomberg, I. (2007). 'Prikaspiiskii gazoprovod protiv Navukhodonosora', RIA Novosti, 24 December, available at: http://www.rian.ru/analytics/20071224/93944073.html, accessed 20 February 2008.

Trenin, D. (2005). 'Russia, the EU and the Common Neighbourhood', Centre for European Reform Essays, available at: http://www.cer.org.uk/pdf/essay russia trenin sept05.pdf, accessed 16 August 2007.

Trenin, D. (2006). 'Russia Leaves the West', Foreign Affairs, July/August.

VCIOM (2005). 'Rossiyane - protiv usileniya Zapada v stranakh SNG' Public Opinion Survey, available at: http://wciom.ru/arkhiv/tematicheskii-arkhiv/item/single/1252.html, accessed 20 August 2007.

Vinokurov, E. (2007). 'Russian Approaches to Integration in the Post-Soviet Space in the 2000s', in K. Malfliet, L. Verpoest and E. Vinokurov (eds), The CIS, the EU and Russia: The Challenges of Integration. New York: Palgrave Macmillan.

Voice of Russia (2007a). 'ES ne podderzhivaet negativnuyu pozitsiyu 'mladoevropeitsev' po SEG', 12 December.

Voice of Russia (2007b). 'Mirovoi energetichesky rynok i rossiisky gaz', 16 July.

Voice of Russia (2007c). 'Rossiya - ES', 21 May.

Yunanov, B. (2007). 'Evropa poluchit odnu trubu', Moskovslie novosti, 18 May, p. 20.

Zagorski, A. (2005). 'Russia and the Shared Neighbourhood', in D. Lynch (ed) What Russia Sees, Chaillot Paper 74, Paris: Institute for Security Studies, pp. 61-77. 